This is a pre-copyedited, author-produced version of an article accepted for publication in Social History of Medicine following peer review. The version of record, "Kathleen McIlvenna, Douglas $\mathrm{H} \mathrm{L}$ Brown, David R Green, 'The Natural Foundation of Perfect Efficiency': Medical Services and the Victorian Post Office, Social History of Medicine, Volume 33, Issue 2, May 2020, Pages 539-558", is available online at: https://doi.org/10.1093/shm/hky123. 


\section{'The Natural Foundation of Perfect Efficiency': Medical Services and the Victorian Post Office}

Kathleen Mcllvenna (University of Derby), Douglas H.L. Brown (Kingston University) and David R. Green (King's College London)

\section{Summary}

This article explores the creation of the Post Office medical service. Working for the Post Office was relatively well-paid and an increasing number of doctors were employed. Medical provision expanded with the introduction of non-contributory pensions from mid-century and developed into a comprehensive and nationwide service that was involved at all stages of employment, from initial recruitment through to receiving a pension. Post Office doctors assessed candidates' fitness for work, checked on sick absences, provided free medicine and advice and visited workers' homes. Doctors were responsible for determining whether or not a worker should be pensioned off on grounds of ill health. The career of the first Chief Medical Officer, Dr Waller Lewis, also illustrates the range of other areas in which the Post Office medical service became involved, including the clinical assessment and relief of sickness as well as identifying preventative measures to improve health outcomes.

Keywords: Post Office; medical service; retirement; service sector; ill health

\section{Introduction}

On 23 June 1855 a notice was published in The Lancet. It was short and simple with little fanfare or celebration and read: 'Dr Waller Lewis one of the Metropolitan Commissioners of Sewers has been appointed by Viscount Canning as Medical Officer to the General Post Office. ${ }^{1}$ Sitting among appointments of Poor Law medical officers and charity doctors it could easily have been missed. However, this appointment marked a milestone in the history of occupational health and medical provision, and the beginnings of a service that by 1905 employed 1,832 doctors administering free

\footnotetext{
${ }^{1}$ The Lancet, 23 June 1855, vol. 65, Issue 1660, 641.
} 
medical attendance to 116,541 workers across the United Kingdom. ${ }^{2}$ Throughout the Victorian period and beyond, the Post Office medical service grew substantially so that by the 1930s it was described as 'the largest in the British Empire, if not the world'. ${ }^{3}$ Writing in 1936 Henry Bashford, the Post Office's sixth Chief Medical Officer, described the role of the medical service as going well beyond clinical activities, being a department with a 'peculiarly intimate relationship with the staff' involved in all aspects of the employee's working life that included advising on topics as varied as the shape and material of uniforms, the sanitary state of post offices and workmen's homes, and the weight a boy messenger should be able to carry. ${ }^{4}$

Occupational health is far from a neglected subject for medical or social historians but much of what we know is linked to industrial disasters or particularly dangerous occupations. ${ }^{5}$ Paul Weindling's survey of occupational health published in 1985 outlined the scope of the subject but since then the emphasis has remained on accidents and industrial illness in the more hazardous kinds of trades. ${ }^{6}$ Coal mining accidents and diseases have also been a prominent theme, though as David Selway's work on accidents and memory in South Wales has recently shown mining disasters could be largely absent from the coalfield's collective memory. ${ }^{7}$ Furthermore, considering the significance that some occupational diseases, such as phosphorous necrosis developed from match-making, have played in

\footnotetext{
2 Total number of employees at the Post Office was 192,454 (84,113 were employed full-time on the establishment, and 108,341 were unestablished part-time employees). 1905 [Cd. 2634] Fifty-first report of the Postmaster General on the Post Office, 24, 27.

${ }^{3}$ H. H. Bashford, Post Office Medical Service, (Post Office Green Papers, No. 31, Nov 1936), 3.

${ }^{4}$ Ibid., 10. See also POST 64.7 General Instructions issued to medical officers, December 1880.

${ }^{5}$ For a useful review of the historiography of occupational illness see J. Melling, 'Employers, Industrial Welfare and the Struggle for Work-Place Control in British Industry, 1880-1920', in H. F. Gospel and C. R. Littler, eds, Managerial Strategies and Industrial Relations: An Historical and Comparative Study (Farnham: Ashgate,1983), 55-81.

${ }^{6}$ There is an extensive literature on the dangerous trades. See Bartrip, P. W. J., The Home Office and the Dangerous Trades: regulating occupational disease in Victorian and Edwardian Britain (Amseterdam: Rodophi, 2002). For occupational health more generally see P. Weindling (ed.) The Social History of Occupational Health (London: Croom Helm, 1985).

${ }^{7}$ For recent publications on coal mining and occupational health see A. Mclvor and R. Johnston, Miners' Lung: A History of Dust Disease in British Coal Mining (London: Routledge, 2007); C. Mills, Regulating Health and Safety in the British Mining Industries, 1800-1914, (London: Routledge, 2010); D. Selway, 'Death underground: Mining accidents and memory in South Wales, 1913-74', Labour History Review, 2016, 81 (3), 187-209.
} 
the history of labour and the labour movement it is unsurprising that social and medical historians have focused on these kinds of occupations rather than on conditions in the service sector. ${ }^{8}$

While accidents and industrial diseases were of concern to both government and the wider public, so too was the state of health in the Victorian Post Office and authorities sought to ensure that the workforce was healthy enough to maintain the efficient running of the service. In order to do so from the mid-nineteenth century, the government established a medical service that initially focussed on London, which contained by far the largest concentration of postal workers and was the pivot around which the entire system revolved. The medical service became central to the industrial culture and operations of the Post Office, and over the course of the second half of the century its influence slowly seeped out from the London offices into every part of the United Kingdom.

The Post Office, like the Poor Law, provided one of many possible appointments for Victorian general practitioners to supplement their income and raise their profile within a local area. Figures compiled by Anne Digby demonstrate that although the number of Post Office medical officers was far below those appointed to serve as Poor Law doctors, public vaccinators and Medical Officers of Health, it still consisted of between 9 and 12 per cent of non-hospital appointments for general practitioners between 1860 and $1919 .{ }^{9}$ These figures were larger than the percentage of doctors employed in any other occupational sector outside of the poor law during this period. ${ }^{10}$ Though in many of the smaller offices, doctors were employed on an ad-hoc basis to provide medical care, in

\footnotetext{
${ }^{8}$ The matchwomen's strike in 1888 highlighted the disfiguring effects of phosphorous necrosis and caused a scandal. See Barbara Harrison, 'The politics of occupational ill-health in late nineteenth century Britain: the case of the match making industry', Sociology of Health \& Illness, 1995, 17(1), 20-41; Louise Raw, Striking a Light: The Bryant and May Matchwomen and their Place in History, (London: Bloomsbury, 2011). For discussions about factory work and health see of Vicky Long, The Rise and Fall of the Healthy Factory, (London: Palgrave, 2011), 8-9.

${ }^{9}$ Digby, The Evolution of British General Practice, 80.

${ }^{10}$ Two out of five GPS during the Victorian period had appointments as poor law doctors. Appointments of GPs in schools and the police had similar proportions each employing 7-10\% of Digby's cohort (Table 4.3). Other occupations listed include military employing 4-7\% (Table 4.3), colliery 1-4\%, other quarries, works and mines 1\%, railway and canals 1-3\% and factories 7-9\% (Table 10.1). See Digby, The Evolution of British General Practice, 80, 273. For medical provision in the poor law, see Kim Price, Medical Negligence in Victorian Britain (London: Bloomsbury, 2015), 21-47.
} 
the larger ones the Post Office increasingly came to prefer appointing part-time doctors at a fixed salary with additional fees allowed for the examination of candidates for employment and other duties. ${ }^{11}$ By 1899 there were 580 medical officers based in London and in post offices in large towns and cities throughout England, Scotland, Wales and Ireland arguably providing the largest occupational health service in the country. ${ }^{12}$ Yet, despite the scale of provision, the work of the Post Office medical service has largely gone unnoticed by medical historians.

This is an important gap in our knowledge of occupational health and the provision of medical care in nineteenth-century Britain. In this article, we draw attention to the scale and scope of the Post Office medical service from its beginnings at mid-century, including the appointment of the first medical officer. ${ }^{13}$ It demonstrates that medical officers played an integral role in the working lives of postal employees and potentially beyond the Post Office itself. They were responsible for examining candidates for employment as well as for recommending retirement on grounds of ill health. They were expected to manage the health of staff through monitoring attendance and managing any outbreaks of epidemic disease in the workforce. They provided advice and medicines, visited workers in their own homes when required, and were also responsible for ensuring sanitation in post offices was to a high standard. Although workers may have felt that doctors employed by the Post Office were there to act as a 'medical police', from pension records it is possible to see that medical staff could help the cause of an employee as well as hinder it. They were more than simply gatekeepers to ensure that only the fit and healthy workers were recruited or a medical police to detect malingering, as Alan Clinton has suggested. ${ }^{14}$ Rather, they performed a much wider set of duties related to the overall health and safety of the workforce about which we know relatively little

\footnotetext{
${ }^{11}$ P. J. Taylor and J. Burridge, 'Trends in death, disablement and sickness absence in the British Post Office since 1891', British Journal of Industrial Medicine 39 (1982), 2.

121899 [Cd 9463] Forty-fifth annual report of the Postmaster General on the Post Office, 17-18.

${ }^{13}$ We examine the pattern of ill health in an accompanying article. See David Green, Douglas Brown and Kathleen Mcllvenna, 'Addressing ill health: sickness and retirement in the Victorian Post Office', Social History of Medicine (forthcoming).

141862 letter from the Post Office to the Treasury quoted in Alan Clinton, Post Office Workers: A Trade Union and Social History, (London: George Allen \& Unwin, 1984), 47.
} 
and upon which the entire postal service depended. Finally, by examining the career of Dr Waller Lewis, who became the first Chief Medical Officer, we can begin to understand better the influence and impact that the Post Office medical service had on the health of the workforce in one of the largest and most important branches of public office in the country.

\section{Creating the Post Office Medical Service}

The appointment of the first permanent medical officer at the Post Office in June 1855 marked the start of a period of rapid expansion in medical provision. In the next few years part-time medical officers were appointed in several of the large provincial towns including, Dublin, Edinburgh, Glasgow and Liverpool, but it took the nationalisation of the telegraph in 1870 for the service to expand significantly. ${ }^{15}$ The geographical spread of the medical service shown in Figure 1 highlights the rapid expansion that took place after 1870 . By then around 30 towns and cities outside London had a part-time medical officer assigned to them; by the middle of the decade the number had risen to 52 , and a further 46 officers had been added by the end of the 1870 s, together with an expansion of the service in all the London sub-districts. ${ }^{16}$ In 1883 the first female medical officer, Dr Edith Shore, was appointed at a salary of $£ 350$ to examine all female candidates for the Post Office and to provide care for the large and growing number of female staff in the General Post Office in London. A second female officer was appointed in 1895 to cope with the ever growing volume of work. ${ }^{17}$ The number of medical officers continued to increase throughout the 1880 s and by the 1890 s even post offices in the Shetlands and the Hebrides had their own medical officers. In 1895 it was reported

\footnotetext{
${ }^{15}$ Bashford, Post Office Medical Service, 3. See also Taylor and Burridge, 'Trends in death, disablement and sickness absence, 1-2.

${ }^{16} 1871$ [Cd 438] Seventeenth report of the Postmaster General, on the Post Office, 25; Post Office Archives, POST 64/1, The Post Office Medical Service, 155-65, 189, 228-230.

${ }^{17} 1883$ [Cd 3703] Twenty-ninth report of the Postmaster General on the Post Office, 3; POST 64/1, 750-60; See also M. L. C Madgshon, 'Woman medical officer to the Post Office, 1883', Wellcome Library, SA/MWF/C/62.
} 
that there were 480 doctors employed by the Post Office: four at the main post office in London with 45 in the other metropolitan districts, 385 in the rest of England and Wales, 22 in Scotland, 21 in Ireland and three female medical officers, one based in London and one each in Liverpool and Manchester. ${ }^{18}$ As the number of postal employees continued to grow, so too did the number of medical officers and by 1901 there were at least 597 doctors attached to the Post Office, including four female officers, in charge of 77,165 men and 10,077 women. ${ }^{19}$

181895 [Cd 7852] Forty-first report of the Postmaster General on the Post Office, 15-16; POST 64/1, 946.

${ }^{19} 1901$ [Cd 762] Fort -seventh report of the Postmaster General on the Post Office, 22. 


\section{Decade [Number]}

- Before 1870 [9]

- 1870s [96]

- 1880s [60]

1890s [29]

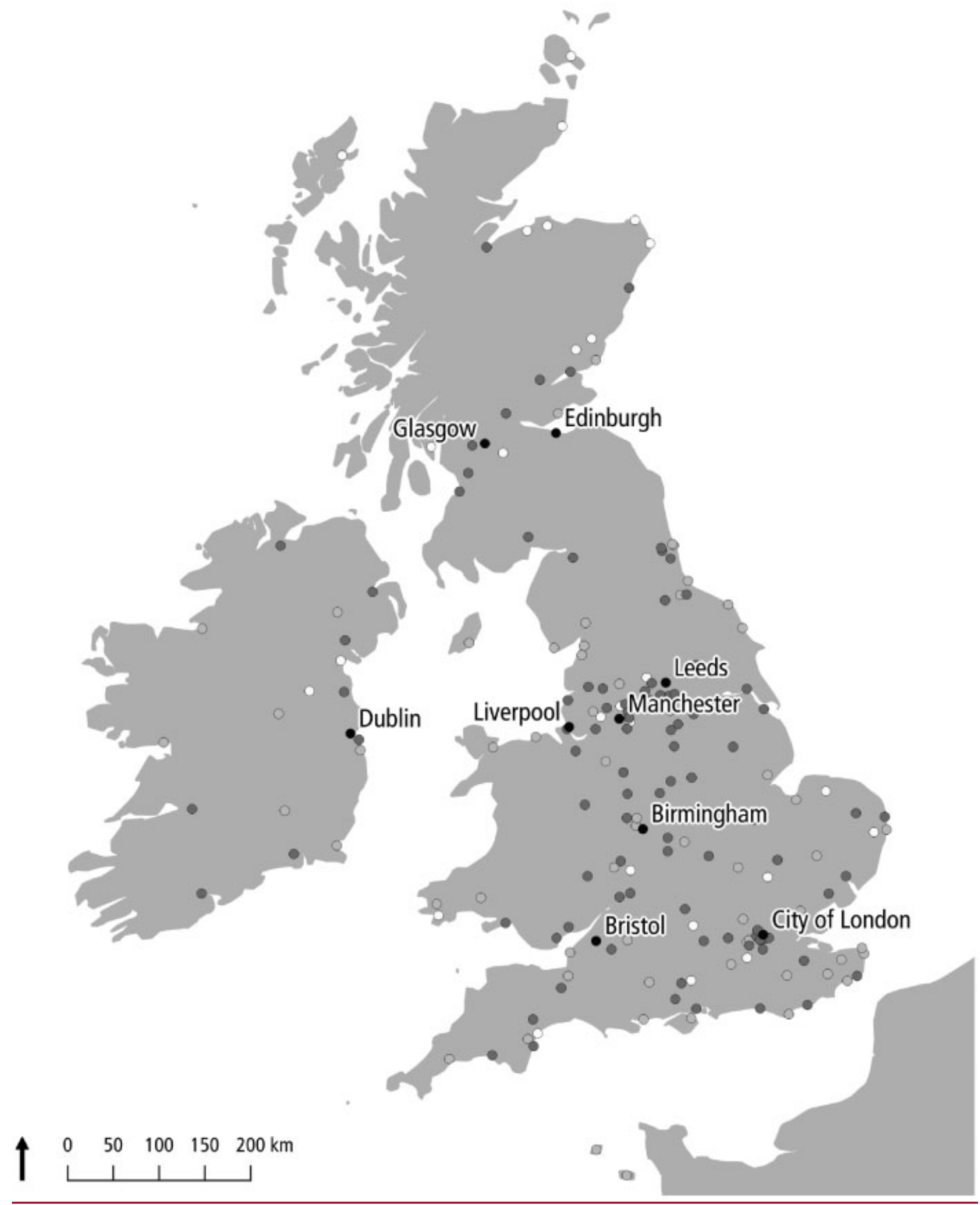

Figure to be insed

Figure 1: Places with a Post Office Doctor 1855 to 1895. 


\section{Source: Postal Museum Archives, Post 64/1, The Post Office Medical Service.}

Though the large number of medical officers suggests a fairly active department, initially only a handful of those based at the London headquarters, and in later decades in a few of the larger urban centres, were ever full-time, salaried employees. The decision whether or not to appoint a part-time medical officer was based on the size of the workforce in each post office district. Until 1876, offices with less than 40 workers were attended on an ad-hoc basis, with private doctors paid a fee for any services provided. After 1876, this figure was reduced to 20 staff. ${ }^{20}$ For offices above this size, it was considered more economical to make a part-time appointment rather than to continue to call on the services of a private doctor. ${ }^{21}$ Part-time doctors were permitted to continue with private practice but where they were employed on a full-time salary, they were expected to devote their time entirely to the Post Office. By the time Dr George Carrick Steet became the second Chief Medical Officer following Dr Waller Lewis's death in 1882, the full-time officers included the Chief and Deputy Medical Officers and a soon-to-be-appointed female medical officer, together with full-time doctors in the largest post offices. From the 1860s there was also at least one full-time assistant role in London to support the Chief Medical Officer. ${ }^{22}$ By the mid-1930s there were eleven full-time medical staff in London, including the Chief and Deputy Medical Officers, a senior female medical officer and eight assistants, four male and four female. ${ }^{23}$

Working in the Post Office was just one of the various other appointments a Victorian doctor could hold but it was a relatively lucrative one compared to other forms of public service. Digby has shown that remuneration from appointments could make up to a fifth or even a quarter of a doctor's

\footnotetext{
${ }^{20}$ Taylor and Burridge, 'Trends in death, disablement and sickness absence', 2.

${ }^{21}$ The situation was under constant review and requests for further appointments were made on an ongoing basis by the Chief Medical Officer to the Postmaster General. See POST 64.1, Post Office Medical Service, 1129.

22 POST 64/1 Post Office Medical Service, 136; See also POST 1/231, Treasury Letters 1891, 335.

${ }^{23}$ Bashford, Post Office Medical Service, 4.
} 
income between 1870 and 1910 s. $^{24}$ One of the appointments most frequently held was as medical officer to the local poor law union, frequently combined with private practice. Poor law doctors, however, were relatively poorly paid and throughout most of the nineteenth century on average received a starting salary of less than $£ 50 .{ }^{25}$ Only in the larger unions were salaries much higher: in Birmingham the medical officer's pay rose in 1861 from $£ 150$ to $£ 200$ a year plus board, lodging and a servant, but then returned to $f 150$ in $1890 .{ }^{26}$ However, this was the exception and the large majority of poor law doctors worked for far less.

Though the payment of Post Office medical officers also came out of the public purse, their remuneration came from the Post Office grant rather than from often hard pressed and parsimonious ratepayers, as was the case with poor law doctors, and therefore they were on the whole better paid than other appointments. Payment was mainly based on a small retainer, and a capitation fee based on the number of employees in their charge. By the 1870 s the Post Office had settled on a rate of $8 \mathrm{~s} 6 \mathrm{~d}$ per capita for officers on the 'regular list', which would include all employees eligible for free medical attendance, with additional fees for extra services. ${ }^{27}$ This remuneration was expected to cover drugs and medical attendance, but Post Office doctors also received an extra 10s per head for examinations of new recruits as well as fees for a range of other services. . There was also an additional $8 \mathrm{~s} 6 \mathrm{~d}$ for attendance of postal employees not on the 'regular list', but who were suffering from specific illnesses. ${ }^{28}$ The amount a medical officer could receive could therefore vary considerably, depending on the size and number of the post offices they served. In 1855 permanent medical officers were appointed in Dublin and Edinburgh at salaries of

\footnotetext{
${ }^{24}$ Anne Digby, Making a Medical Living: Doctors and patients in the English Market for Medicine, 1720-1911, (Cambridge: Cambridge University Press, 1994), 123.

${ }^{25}$ Kim Price, Medical Negligence in Victorian Britain: the crisis of care under the English Poor Law, c. 1834-1900 (London: Bloomsbury, 2015), 38-41.

${ }^{26}$ Jonathan Reinarz and Alistair Ritch, 'Exploring Medical Care in the Nineteenth-Century Provincial Workhouse: A View from Birmingham', in Reinarz and Schwarz, eds, Medicine and the Workhouse, 148-149. 27 POST 64/1, 397-398; POST 68/81 Rules for Provincial Head Postmasters (United Kingdom) 1893, 21. ${ }^{28} 1907$ (Cd 266) Report from the Select Committee on Post Office Servants; with the proceedings of the committee, 93.
} 
f100 and $f 160$ respectively, with an additional 10 s for examining clerks and $5 \mathrm{~s}$ for letter carriers. ${ }^{29}$ Together with their part-time salary, the additional fees could be significant. For example in 1890 the Liverpool Post Office included 462 established postmen who would have been on the 'regular list' and the medical officer there was guaranteed an additional capitation income of at least $f 181 \mathrm{a}$ year, whereas Edinburgh employed 248 established postmen which would have generated at least $£ 105$ a year. ${ }^{30}$ This rate of pay was far in excess of most Poor Law doctors and for the rest of the century remained well above the rate that doctors received from friendly societies and from acting as police surgeons. ${ }^{31}$

\section{Examinations and Recruitment}

From the outset, one of the main tasks of the medical officers was the physical and mental examination of candidates applying to the Post Office. The medical examination, however, served several purposes over and above ensuring the fitness of candidates for office. Medical examinations were first recommended in a report by Sir Stanley Northcote and Sir Charles Trevelyan in which they considered that a certificate should be produced to prove candidates for the Civil Service had 'no bodily infirmity likely to incapacitate them from the public service' ${ }^{32}$ This was then echoed in a report on the Post Office published in 1854 which recommended that medical examinations should be used to ensure new recruits had no 'physical or mental defect or disease' which might hinder their employment in the service. ${ }^{33}$ By 1856 an examination was required upon recruitment and again after the probation period, at that time a period of six months but later extended to two

${ }^{29}$ Post 64/1, 78.

${ }^{31} 1907$ (Cd 266) Report from the Select Committee on Post Office Servants; with the proceedings of the committee, 93. For a comparison with Poor Law doctors see Price, Medical Negligence, 37-39.

${ }^{33}$ POST 64/23 Probation and Medical Examinations: Report of Committee., 22 May 1894, 1. 
years. ${ }^{34}$ Postal workers who developed a disease during their probationary period were liable to be dismissed. ${ }^{35}$ The tests that candidates had to pass before becoming 'established' or permanent employees also linked the medical examination with the shift from patronage to a more meritocratic system of appointment, making merit measurable not by their personal connections but by the physical condition of the applicant as well as their intelligence. Good health was therefore linked to more modern forms of appointment and to good public service - and once pensions became more widespread it was also a simple matter of economy, since premature retirement because of poor health was a drain on the public purse. ${ }^{36}$

In the period between 1855 and 1860 medical examinations began to filter into other parts of the working life of the Post Office. In 1859 pensions were introduced for all employees who had worked for the Civil Service, including the Post Office, for over ten years, and for those retiring because of illhealth a medical examination and certificate were compulsory. ${ }^{37}$ For those who had worked for less than ten years, but whose health was poor, a medical examination and recommendation could also be the basis for being granted a gratuity. During this period sick and holiday pay were also introduced and with the availability of sick pay came the necessity of a doctor's certificate. Consequently, medical examinations became a routine part of Post Office employment for the entire duration of an officer's working life from their initial application to the point of their departure from service.

The requirements of the recruitment process can be found in the rules and instructions books for Head Postmasters and consisted of a series of forms and signatures that included a detailed medical report. ${ }^{38}$ The candidate's age, height, weight and chest measurement were recorded; they were

\footnotetext{
34 Ibid., 3.

35 Ibid., 3.

${ }^{36}$ The growth of meritocratic forms of appointment is explored more widely in Harold Perkin, The Rise of Professional Society (London: Routledge, 1989).

${ }^{37}$ For a discussion of Post Office pensions, see David Green, Douglas Brown and Kathleen Mcllvenna, 'Addressing ill health: sickness and retirement in the Victorian Post Office', Social History of Medicine (forthcoming).

${ }^{38}$ See POST 64/1, 1001-1002.
} 
asked questions about their previous medical history and that of their families, including whether they had suffered from consumption or smallpox; their urine was tested and their heart, hearing and respiration were examined. They were asked if they had been vaccinated and checked whether they suffered from rupture, piles, varicose veins and flat feet. Finally the medical officer had to signify if a candidate was deemed fit enough to start work and the form then passed to the postmaster for final completion. ${ }^{39}$ The nomination form was received from the local postmaster and part of it had to be completed in the presence of his 'ordinary medical attendant, or, if he have none, to some qualified member of the medical profession. ${ }^{40}$ In many parts of the country this service had to be paid for privately and the cost was expected to be met by the potential employee. ${ }^{41}$ Only when the nomination form, including the medical statement, was approved by the local surveyor, and then the Secretary of the Post Office, could the candidate be put forward for the Civil Service Examination. ${ }^{42}$ Once this was completed and approved, a candidate was put on probationary appointment for a period of six months, later extended to two years. After this time, a 'probation report' was completed, and for offices with a medical attendant attached, this included a second medical examination. ${ }^{43}$ Once this was approved the candidate was finally officially appointed and became an established member of staff with the benefits that came with that role, including free medical care..

In London there was concern that an insufficient proportion of those seeking work were physically robust enough to undertake employment. ${ }^{44}$ Observing that 'a considerable number of those who present themselves for medical examination are small, slightly made, and sickly looking', Dr Waller

\footnotetext{
39 Ibid.

40 POST 68/75 Rules for Head Postmasters in England and Wales 1860, 7.

${ }^{41}$ Ibid.

${ }^{42}$ Outside London the surveyors had responsibilities for overseeing post offices in different parts of the country, including recruitment. In 1885 there were 16 surveyors. See Martin Daunton, Royal Mail: the Post Office since 1840 (London: Athlone, 1985), 280-285.

43 POST 68/75 Rules for Head Postmasters in England and Wales, 8. For offices without a medical attendant, it appears that no further examination took place.

${ }^{44}$ The term letter carrier was used until the delivery of parcels was added to the postal service in 1885 at which point the term was changed to postman. See Daunton, Royal Mail, 10.
} 
Lewis recorded a list of the applicants' previous occupations. ${ }^{45}$ The top three were domestic and other servants, sorters and messengers, and clerks in counting houses, but he singled out agricultural labourers as being a group of applicants that had decreased over the years and one he felt would be better suited as letter carriers for their 'strong muscular development' ${ }^{46}$ Waller Lewis emphasised that it was not the work of the letter carrier that was unhealthy, arguing that in the previous ten years seven men had retired following fifty years of service, but warned that the work would be detrimental to the health of those who were 'of impaired health... undersized in stature, or weakly framed. ${ }^{\prime 47}$ He expressed further concern that even where they had been passed fit, many applicants failed the Civil Service exam that tested their intellectual abilities. Of the 257 men approved by him as physically able and meeting other requirements relating to age and character, 89 or 34 per cent did not pass the academic test. ${ }^{48}$ He ruefully remarked that the requirements for letter carriers to pass Civil Service Commission exams was resulting in better educated men but not those 'accustomed to healthy out-of-door employments'. ${ }^{49}$

The inclusion of Waller Lewis's concerns in the Postmaster General's annual report suggested some sympathy with his views, but it was not an area that the Postmaster General had any power to change and it would be up to the new Civil Service Commission, the Treasury or even Parliament to act upon this evidence. The criticisms from Waller Lewis, still relatively new to the post, might have fallen on deaf ears, but concerns regarding the physical quality of candidates did not disappear, particularly in the context of difficulties in recruiting sufficient numbers of fit and healthy workers in towns and cities. In 1859 the minimum height for a letter carrier was reduced from $5 \mathrm{ft} 5 \mathrm{in}$ to $5 \mathrm{ft}$ 3in because of the high rate of rejection and consequent shortage of recruits, and in 1860 there was even a proposal to remove the height requirement altogether. By the 1880s, the Post Office had

\footnotetext{
45 Ibid., 69.

46 Ibid., 70.

47 Ibid., 70.

48 1857-58 [Cd. 2342] Fourth report of the Postmaster General on the Post Office, 69.

49 Ibid., 31.
} 
settled on a height of $5 \mathrm{ft} 4 \mathrm{in}$ for provincial letter carriers, with a minimum chest measurement of 29 $1 / 2$ inches. ${ }^{50}$ By the turn of the century, however, the Post Office felt compelled to set up a committee to examine the subject further, though no change in policy appeared to result and there was no further reference to the committee in the Postmaster General annual reports. ${ }^{51}$

Although Dr Waller Lewis might not have had much influence in encouraging the Post Office to relax the Civil Service examination, he did support the extension of the probationary period that postal workers were expected to serve, and the introduction of medical examinations over a comparable term. As the service began to change, with the nationalisation of the telegraph in 1870 and the increasing employment of women and younger adults, many of whom were boy messengers, new measures began to be introduced. In 1876 the probation period was extended to twelve months for clerks of the lower divisions and the body of boy clerks. ${ }^{52}$ Fourteen years later the Postmaster General decided to accept a recommendation to extend the probation period for sorters and telegraphists to two years, and by August 1891 this was extended to include all postmen. A report in 1894 recommended this length of probation should be applied equally to all employees except second division clerks and boy clerks. ${ }^{53}$ Together with having to pass a lengthy probation period, employees were also expected to undergo three separate medical examinations, one upon entry to the service, one at six months and another at the end of the two years' probation. ${ }^{54}$ If weak candidates could not be weeded out at an early stage, it was argued, it was even more necessary to have an extended probationary period during which they were expected to maintain good habits and good health.

\footnotetext{
50 POST 64/1, 974-983.

${ }^{51} 1900$ [Cd 333] Forty-sixth report of the Postmaster General on the Post Office, 22

52 POST 64/23 Probation and Medical Examinations: Report of Committee, 22 May 1894, 3.

${ }^{53}$ Ibid., $3,5$.

${ }^{54} 1897$ (Cd 121) Post Office establishments. Copy of report of the inter-departmental committee on Post Office establishments, together with the Treasury letter thereon, dated 9 March 1897, 7; 1897 [Cd 163] Post Office establishments. Return to an order of the Honourable the House of Commons, dated 6 April 1897;--for, copy "of evidence (with indices, summaries, and appendices) taken before the committee in Post Office establishments.", 436.
} 
Though other Civil Service departments including the Admiralty, Board of Trade, Customs, Inland Revenue and War Office all had medical officers, the Post Office was the only department to test the physical fitness of candidates once they had entered the service ${ }^{55}$ In the 1890s Dr Arthur Wilson, the third Chief Medical Officer, defended this policy on the grounds that the Post Office employed many young people and it was important to help ensure they developed good habits and maintained excellent health from the start. Wilson even suggested that this lengthy probationary period should remain in place until an employee reached the age of 21 , irrespective of when they joined the service. ${ }^{56}$ The health of the body of postal employees directly impacted on the efficiency of the Post Office and convenience of the public and it was argued that under those circumstances extra medical precautions should be taken.

For six months, or a year even, these shiftless lads may perhaps put pressure upon themselves to keep as straight and as well as may be; but a year is not much time in which to form a sane habit of life and foster a stalwart frame of mind. We do not pretend to say that two years can suffice for the making of good men from the class of candidates of whom but too many become postmen; but we do say that two years of self-restraint and care must, in the nature of things, be more than twice as beneficial as one year; because self-restraint and care are as cumulative in their effects as their opposites are; and we think there may be ground for hoping that in many cases such a term of probation would have a solid effect on the character. ${ }^{57}$

Wilson's view was founded on the experience of the second examination at six months which, in 1893 , produced a rejection rate of 25 per cent, justifying, in his eyes, the need to have a structure in

\footnotetext{
55 POST 64/23 Probation and Medical Examinations: Report of Committee, 22 May 1894, 6.

561897 [Cd 163] Post Office establishments, Return to an order of the Honourable the House of Commons, dated 6 April 1897, 436.

57 POST 64/23 Probation and Medical Examinations: Report of Committee, 22 May 1894, 16.
} 
place to monitor the health of the youngest employees at the Post Office ${ }^{58} \mathrm{His}$ feelings were best articulated in the 1894 departmental committee on probation:

... there is no Department of the State which is so completely and vitally in touch with the public as the Post Office is; that any want of efficiency in the Service of the Post Office would tend to inconvenience the public at numerous points in its everyday existence, and that for a body of public servants whose failings are so highly capable of causing daily and hourly inconvenience, the first essential is that sanity of body which is the natural foundation of perfect efficiency. ${ }^{59}$

However, despite these concerns, the 1896 Tweedmouth Committee did not concur with Dr Wilson's views and recommended that the probation period be lowered to one year with only two medical examinations. ${ }^{60}$ Expediency and economy, in this case, took precedence over the more cautious approach advocated by the Chief Medical Officer.

\section{Attendance and Superannuation}

Recruitment may have been one of the principal reasons for the employment of medical officers, but they had other important responsibilities relating to attendance at work and the grant of a pension. Depending on the salary of the employee, Post Office doctors were required to provide free medical assistance to established workers who lived within three miles of their normal place of work, visiting them in their own homes and supplying medicine where needed. Workers were able to use their own doctor, but if they did so they had to bear the cost and any certificate provided to prove the

\footnotetext{
${ }^{58} 1897$ [Cd 163] Post Office establishments. Return to an order of the Honourable the House of Commons, dated 6 April 1897;--for, copy 'of evidence (with indices, summaries, and appendices) taken before the committee in Post Office establishments.', 437. ${ }^{59}$ POST 64/23 Probation and Medical Examinations: Report of Committee, 22 May 1894, 6.

${ }^{60} 1897$ [Cd 121] Post Office establishments. Copy of report of the inter-departmental committee on Post Office establishments, together with the Treasury letter thereon, dated 9 March 1897, 7.
} 
worker was unfit to undertake duties still had to be countersigned by the Post Office's own doctor. Established sorters, stampers, letter carriers, porters, messengers and other workers who earned less than $£ 150$ a year were entitled to receive free medical advice and medicines whilst those who earned above that amount were able to receive free advice but not medicines. ${ }^{61}$ Over time, these benefits were extended to other groups of workers: in the 1870s telegraphists, telegraph messengers and auxiliary letter carriers were entitled to free assistance and in the 1880 s temporary and auxiliary workers who delivering letters, parcels and telegrams were also included. ${ }^{62}$ Doctors were reminded on more than one occasion that even in cases of venereal disease, workers were still entitled to receive free care. ${ }^{63}$ In practice, therefore, over time most workers engaged in sorting and delivering the mail became entitled to free medical assistance.

Free medical attendance served two purposes. First, it encouraged workers to report illness at an early stage rather than continue to work when unwell and given the fear of infectious disease, this was an important consideration. Secondly, however, because sickness pay was available at comparatively generous rates, doctors were needed to detect malingering. In the case of extended sickness absence, a doctor could recommend retirement on health grounds if they did not believe the employee would recover sufficiently to return to work. Writing to the Postmaster General in 1886 to request an increase in the medical service, Sir Arthur Blackwood, Secretary to the Post Office, noted the central role that the medical officers played in these kinds of decisions: 'It is impossible to exaggerate the importance of this system of Medical Supervision as a means of checking absence on a false or insufficient plea of illness and of arresting illness in its incipient stages, whereby a prolonged absence with all the attendant inconvenience and expense of providing

\footnotetext{
61 POST 64/1 29-43

62 Ibid., 155, 197, 295, 357.

63 Ibid., 123, 311.
} 
for the absentee's duties may be avoided. On those grounds alone I should strongly recommend the extension of the Medical system. ${ }^{64}$

It was the medical examinations and decisions based around these sick pay and retirement that caused the most contention between employees and management. Sick pay was relatively generous and therefore always presented an inducement to stay away from work. Any absence has to be certified by a Post Office doctor but providing that took place, a worker became entitled to full pay for the first six month's absence, and half pay for the next six months. Providing that a Post Office doctor certified that an employee would be able to return to work, it was also possible to receive half pay for another six months, though this was later reduced to one-third. Although the precise terms and conditions changed over time, in general established workers remained entitled to these benefits throughout the period with doctors central to the decision making process regarding sick pay.

For the Post Office, sick pay helped with retention of staff, but it also presented an inducement to malingering and the medical service was therefore an important means of checking on unwarranted absences. From the Treasury's and the Post Office's perspective the employment of medical officers was a necessary measure to ensure that only the healthy were recruited, workers remained well, the long term sick retired and malingering detected. ${ }^{65}$ Alan Clinton, however, argues that workers were often hostile to medical involvement and interference, describing the Post Office doctors as the 'Medical Police' acting on the instruction of their paymasters and not for the welfare of individual workers. ${ }^{66}$ Years of dissatisfaction among postal employees regarding pay and promotion eventually resulted in the establishment of a Select Committee in 1906 where postmen's representatives

\footnotetext{
64 Ibid., 304.

${ }^{65}$ Clinton, Post Office Workers, 47.

661862 letter from the Post Office to the Treasury quoted in Ibid., 47.
} 
described the doctors employed by the Post Office as a 'detective force' and clerks as 'an official "whip"'. ${ }^{67}$ Workers who took time off for repeated bouts of illness, or who were considered to be shamming sickness, could be disciplined and lose stripes - and pay - awarded for good conduct and attendance. Not surprisingly, therefore, distrust could easily develop between postal workers and doctors employed by the Post Office.

Through the superannuation applications it is possible to see to what extent the workers were justified in their view. Medical officers were integral to the superannuation system that emerged after 1859. This system was designed to encourage employees to remain with the Post Office for longer, as their superannuation allowance increased by a sixtieth every year of work up to forty years' service, and employees had to be either over 60 or certified as too ill to work to be pensioned off. Pensions were also non-contributory which was important because it allowed the Treasury discretionary authority over the amount granted. ${ }^{68}$ This gave greater power to the medical officer and the employee's superiors as their reports could influence the amount that a worker eventually received. Any account of insubordination or misdemeanours in their working history could result in a deduction from their final pension and repeated sick leave could result in a reduction of salary, and therefore of the final pension. ${ }^{69}$

Equally the medical officer's opinion was not only important in determining if an employee was too ill to work and unlikely to recover, but they were also asked to judge the cause of the illness and certify it was not due to the employee's own actions. This was a difficult issue, particularly in relation to the effects of venereal disease, which generated opposing views within the medical service and

\footnotetext{
${ }^{67} 1906$ (Cd 380) Index and digest of evidence to the report from the Select Committee on Post Office Servants, 334, 552.

68 From the pensions records it is possible to identify how amounts were calculated. For example, William King earned, including allowances, $f 5918 \mathrm{~s} 3 \mathrm{~d}$ a year. He served for 23 years and therefore was entitled to a pension of $23 / 60$ or $£ 22$ 19s. However, he had been off sick for 284 days and consequently was given an allowance of $f 21$ 19s $9 \mathrm{~d}$. See POST 1/227.

69 Postal workers were awarded stripes and additional pay for satisfactory service, including attendance. See 1913 (Cd 268) Report from the Select Committee on Post Office Servants (Wages and Conditions of Employment), 9 for a description of the stripes system.
} 
differing practices across the country. ${ }^{70}$ The process of medical discretion was well illustrated in the case of Thomas McCord, a postmaster in Strabane, Ireland, who applied for superannuation in 1891 after nearly 38 years of service. He was forty-eight years old and had started work as a boy for the British \& Irish Magnetic Telegraph Company before it became part of the Post Office in 1870 . His application for a pension stated he was retiring due to weakness of the heart and lungs. However, in the Secretary's statement it was disclosed that McCord had been suspended for a month as he had 'given way to habits of intemperance', even though he had previously 'discharged his duties with diligence and fidelity to the satisfaction of his superior officers', a set phrase that was repeated in almost all applications. ${ }^{71}$ It appeared that McCord had been under the supervision of the Belfast medical officer who, the Secretary noted, had suggested his drinking may have been the result of failing health. This statement was not as clear cut as the Treasury would have liked and they requested further clarification from an additional medical examination, one that made clear if the illhealth that forced McCord to retire was 'connected in any way with the habits of intemperance'. The doctor's response has not survived, but the Treasury deducted an amount from the full pension McCord was otherwise entitled to, suggesting that doubt existed and merited a reduction. ${ }^{72}$ Personal failings were clearly an important factor in determining the amount of pension and this assessment also applied to medical opinion. Over the course of the nineteenth century it was increasingly important to prove that the illness for which the employee was retiring had not been detected at any stage of the recruitment or probationary process. Out of the 285 applications for retirement due to ill-health in 1891, eighty cases, over a quarter, referred to the employee's previous medical examinations. The reference was generally made in the Secretary's supporting statement and declared that there had been no sign of their current illness or ailment during previous medical examinations at their recruitment or at the end of their probation. Of these eighty

\footnotetext{
70 See POST 64.1, 313-96 for discussions of this point.

71 POST 1/229, 420, 481-484.

72 POST 1/229, 481-484.
} 
applications the vast majority involved a request for a gratuity (65 out of 80 ), which meant that the person had served for less than ten years at the time they were asking for a pension. One application, from Robert Winthrop, a 28 year old rural postman, even referred to the employee's family medical history that would have been taken at the initial medical examination to underline that there had been no indication that this employee was likely to suffer from ill health. Robert had been based in Stocksfield, Northumberland and after working for the Post Office for nearly eight years (only five of which were on the establishment) he applied to retire because of 'mental derangement' ${ }^{73}$ Unfortunately there are no further details concerning the reasons for his early retirement and none of the medical certificates survive for the pension applications, but there was clearly something about his ailment that the Post Office Secretary considered necessary to explain, removing blame from the medical officer who had conducted the initial examination.

In the above examples the needs of the Post Office and Treasury officials sat at the heart of the medical officer and Secretary's response. The pension records sought to determine the extent to which poor health had been brought on by the employee themselves, but also to remove blame from the medical officers in failing to spot reasons for early retirement during the recruitment process. However, the testimony of the medical officer was also able to lay blame at the Post Office's door for the premature retirement of staff. This was particularly useful for staff members who may not otherwise have qualified for a pension or much of a gratuity, such as Elizabeth John, a 70 year old part-time postwoman in Newlyn, Cornwall. In April 1890, while on her rounds, she tripped over a flight of steps and broke a bone in her thigh. ${ }^{74}$ Due to her part-time and unestablished status, Elizabeth did not qualify for a pension. However, because her accident had happened while on duty, along with a sympathetic statement from the Secretary that detailed her service 'in one

\footnotetext{
73 POST 1/231, 197.

${ }^{74}$ POST 1/227 Treasury Letters, 13.
} 
capacity or another for upwards fifty years', the Treasury agreed to give her a compassionate gratuity of $£ 20 .{ }^{75}$

An important aspect of the medical officers' role arose through their sustained relationship with employees over the course of their working lives. Medical officers who were familiar with the worker's history of employment were able to attribute disease and sickness to previous accidents or activities that happened at work. In 1884 Henry Lewis, a London postman, was knocked down by a cart whilst carrying a collection of letters back to the office. As a result of the accident his knee had been fractured and he was off work for several months. Seven years later, aged just 49, Lewis had to apply for retirement due to chronic synovitis. This ailment was attributed by the district medical officer to the earlier fracture and as a result of this he was given a full pension of $£ 3610$ s a year and a one-off compassionate gratuity of $£ 30$ for the original injury. ${ }^{76}$ This example, and others which appeared in the pension records, demonstrate that although employees may have felt that the medical officers were purely there to spy on them, their role could also be beneficial. The medical officers were not just there to detect and deter malingering but were able to help employees present a case to the Treasury that assisted in gaining a gratuity or pension on the grounds of an injury sustained at work.

\section{Extending the Medical Service: Dr Waller Lewis, the first Chief Medical Officer (1855-1882)}

Medical examinations and the provision of care consumed a considerable amount of time and effort but they were not the only responsibilities that a medical officer was required to undertake. Many of the tasks that became an accepted part of their role were established during the tenure of the first medical officer to the Post Office, Dr Augustus Waller Lewis, from 1855 until his death in service in 1882 , and it is worth considering these broader aspects of the service through the lens of his career.

\footnotetext{
75 Ibid.

${ }^{76}$ POST 1/226 Treasury Letters, 182.
} 
His wider interests in public health helped to frame how the Post Office medical service developed from its inception until later in the century.

The appointment of Dr Waller Lewis as the first permanent medical officer came unexpectedly. One of the first tasks that the great postal reformer Rowland Hill, who had been appointed Secretary to the Post Office in 1854, undertook was to employ the services of Dr Hector Gavin to help in the London offices during the cholera outbreak of that year. ${ }^{77}$ Gavin was a well-known sanitary reformer with considerable experience in managing the disease. At the same time as his appointment to the Post Office, however, Gavin was also posted to the Crimea as the sanitary commissioner to the army where he tragically died a year later when his brother's gun backfired, mortally wounding him. ${ }^{78}$ However, Gavin's short tenure at the Post Office left a legacy: the Postmaster General's annual report of 1855 recorded that there has been only two deaths from cholera out of a workforce of nearly three thousand and he attributed the low death rate to Gavin's sanitary interventions. ${ }^{79}$

With the importance of sanitary improvements recognised it needed little further justification to appoint swiftly a replacement with similar experience and Rowland Hill turned to Dr Waller Lewis, a man who had worked closely with Hector Gavin on several previous occasions. ${ }^{80}$ Waller Lewis was a prominent public health campaigner who had joined Gavin as a superintending medical inspector of the General Board of Health during the cholera epidemics of 1848-9 and 1853-4. He was well known in the medical profession and his research into the impact of decomposing bodies in vaults and catacombs, published in The Lancet in 1851, influenced the Burial Act of 1852 which hastened the closure of overcrowded parochial burial grounds in London and encouraged the creation of large, suburban cemeteries away from the city. ${ }^{81}$ By 1854 Waller Lewis' profile was rising as a result of his

\footnotetext{
77 The Morning Post (London, England), Monday, May 7, 1855, 4.

78 lbid.

79 1854-55 [Cd 1913] First Report of the Postmaster General on the Post Office, 50.

80 The Morning Chronicle, September 21, 1853; The Morning Post, May 29, 1850.

81 The Lancet, 1851, 58, issue 1458, 9 August 1851, 121-126.
} 
involvement, alongside Gavin, in managing the cholera outbreak in Newcastle in the previous year, and in a campaign to prohibit new law courts being built in the central gardens of Lincoln Inn Fields. ${ }^{82}$ He subsequently joined the then Secretary of State, Lord Palmerston, at his seat in Broadlands, Hampshire to attend the cholera epidemic there, building up an important political network of support in the process. ${ }^{83}$ His work had clearly impressed Palmerston because in the following November Waller Lewis was asked to write a report on the regulation of noxious trades and occupations in foreign countries, and was then appointed to join the Metropolitan Commissioners of Sewers. ${ }^{84}$ His profile and reputation was such that The Lancet saw him as one out of only two worthy and qualified candidates to replace Mr Simon as the City of London Medical Officer of Health and it showed its regret in October 1855 that he was not available to take up the position. ${ }^{85}$ Waller Lewis had been discussed as a possible candidate only the week before, so it was likely that he had withdrawn his application in favour of taking on the permanent post of medical officer at the Post Office, a position he was to hold for nearly thirty years until his death in 1882.

As the first medical officer at the General Post Office - a title that was altered to Chief Medical Officer in 1873 upon the appointment of a deputy - Waller Lewis was responsible for one of the largest workforces in the country. Initially his responsibilities were mainly confined to London, but even so he singlehandedly had to oversee the health of nearly 1500 employees, as well as attending to medical provision in offices in the rest of the country. ${ }^{86}$ Despite the heavy workload, he was keen to explain to a wider public the treatments he had introduced into the Post Office to deal with a

\footnotetext{
${ }^{82}$ A letter from Dr Waller Lewis to the Board of Health on the matter of new law courts was favourably reported on in The Lancet 1854, 63 issue 1601, 6 May 1854, 500-501.

83 His appointment to accompany Lord Palmerston and his wife to Broadlands was reported in The Lancet, 64, Issue 1618, 2 September 1854, 203.

84 The Lancet, 64, Issue 1629, 18 November 1854, 419; The Times, 9 August 1866. In his capacity as a leading member of the Epidemiological Society of London Waller Lewis also was a regular member of deputations to the government of the day regarding public health. See, for example, British Medical Journal 20 February 1858, 148; Ibid., 17 April 1858 April, 313. Other members included Edwin Chadwick and staff associated with John Simon at the Privy Council. See T. Crook, Governing Systems, 36.

85 The Lancet, 66, Issue 1675, 6 October 185, 328-329.

86 POST 64.1, 85.
} 
variety of common ailments that impacted on the workforce. He wrote to The Times in 1866 describing a treatment for diarrhoea that consisted of opium, ginger, catechu and carbonate of ammonia, with cassia or peppermint water which he had used in relation to cholera during his period at the General Board of Health. ${ }^{87} \mathrm{He}$ also took an interest in the water supply and provided the workers with a drink called 'orangeade' as a preventative measure against water-borne diseases, which was a mixture of sulphuric acid, orange peel and syrup of orange peel added to water. ${ }^{88}$ In 1866 he also supplied the workforce in London with a tonic to be taken at the first sign of diarrhoea consisting of a mixture of 'astringent gum-resin and a diffusible stimulus, with a small quantity of opium and some warm aromatics'. ${ }^{89}$ He continued to contribute to The Lancet sending letters on the importance of smallpox vaccinations, something he made compulsory for all new Post Office employees if they had not previously been exposed to the disease, and the long lasting impact of railway accidents, one of which had led to fatal case of concussion for a mail guard. ${ }^{90}$ Waller Lewis continued to take a broad interest in public health using his position to gather data from Post Office doctors on other medical matters. In 1864 he wrote to the Lancet about the large proportion of women who died in childbirth or shortly afterwards based on information gathered from provincial medical officers during recruitment examinations for the Post Office. His figures showed that two fifths of deaths of the mothers of new postal employees in the provinces had been due to childbirth or a related disease following childbirth, something he felt should only occur to a 'few or none, [and so] deserves the notice of the profession at large'.$^{91}$ Linking this to whether a midwife or doctor was present at the birth, his study had little to do with his duties at the Post Office but rather with the broader interest he took in the overall quality of medical supervision.

\footnotetext{
87 The Times, 9 August 1866;

${ }^{88}$ Ibid.; Morning Advertiser, 14 August 1866.

${ }^{89}$ British Medical Journal, 30 March 1867, 359.

90 The Lancet, 98, Issue 2511, 14 October 1871, 547; idem, 79, Issue 2008, 22 February 1862, 211; 1872 [Cd 645] Eighteenth report of the Postmaster General, on the Post Office, appendix R: Extracts from the Medical Report upon the London Offices for the year 1871, 45-46.

91 'Mortality of parturient women', The Lancet, 83, Issue 2117, 26 March 1864, 367.
} 
Waller Lewis's interests went beyond the immediate treatments of common complaints and he actively lobbied his employers to improve the sanitary conditions of postal workers' homes. Not long after his appointment, he suggested that the Post Office would benefit by building homes for London letter carriers following the example of the 'model lodging houses of the Society for Improving the Dwellings of the Labouring Classes' ${ }^{92}$ As part of his duties, he was required to visit sick workers in their own homes and he was clearly concerned by the conditions he witnessed, describing them as being in the 'most insanitary condition, badly lighted, badly ventilated, and overcrowded', noting 'it is in such abodes that zymotic diseases find numerous victims. ${ }^{93}$ The Postmaster General appears to have supported this idea and in the 1857 annual report states that he was still waiting for a public company to come forward with a proposal for the building project. ${ }^{94}$ However, by the early 1860 s the scheme to build model homes for postal employees had been abandoned through the inability to find a private contractor willing to take on the risk, despite the Post Office's proposal to guarantee rents.

With a rapidly growing workforce and an increasing number of district offices across London, the demands made on Waller Lewis's time rose and he devised new ways to streamline parts of his daily work. In 1860 he put into place a new form of medical examination in which he tried to categorise the candidate's fitness. He employed a 'dynamometer', which tested muscular power and when used alongside information regarding the age, height, weight and chest capacity of the applicant, could be used to establish a strength scale for each candidate. ${ }^{95}$ Using this examination on 128 candidates over a six-month period, he concluded that if the chest capacity (the difference between full inspiration and full expiration) was less than 1.5 inches then the candidate's strength was always likely to be deficient. ${ }^{96}$

\footnotetext{
92 'Reviews and Notices', Association Medical Journal, 4 (176), 1856, 411; 1856 [Cd 2048] Second report of the Postmaster General, on the Post Office, 76-77;

93 Ibid., 77.

941857 Session 1 [Cd 2195] Third report of the Postmaster General on the Post Office, 22.

951861 [Cd 2899] Seventh report of the Postmaster General, on the Post Office, 44-45.

96 Ibid.
} 
Despite his efforts to streamline the work, the scope and scale of Waller Lewis's responsibilities continued to grow and he wrote to the secretary of the Post Office in 1868 asking for an increase of salary by $£ 200$ to $£ 1000$, a request that was turned down by the Treasury which instead recommended a personal allowance of $£ 100 .{ }^{97}$ By 1870 , however, the amount of work had risen even further, particularly with the acquisition of the private telegraph companies by the Post Office and the inclusion of its workforce, a large number of which were women. New appointments of medical officers in some of the larger provincial towns were also made in that year. ${ }^{98} \operatorname{In} 1871$ The Lancet recommended further extension of the Post Office medical service across the country, and supported the idea of this medical provision being introduced across the entire Civil Service. Under the 'headship' of Dr Waller Lewis it noted that the postal medical service had greatly increased in 'magnitude and importance'. ${ }^{99}$ In the years that followed, further extension took place, as discussed above, and by 1876 , nearly a hundred extra post offices in towns and cities had a medical doctor appointed. ${ }^{100}$ To help with the increasing workload, particularly in London, Dr Steet, who was in charge of the telegraph service, was appointed as Waller Lewis's official deputy. ${ }^{101}$ At that point, the Treasury agreed to an increase in Waller Lewis' salary from a starting point of $£ 800$, rising by $f 50$ a year to $f 1000$, in addition to the personal annual allowance of $f 100$ he had already been granted. ${ }^{102}$ Dr Waller Lewis remained in post until his death in October 1882, aged 65 and with a young family, which brought to an end an exceptionally wide ranging and energetic career in which the foundations of the new Post Office medical service had been set. ${ }^{103}$

\footnotetext{
${ }^{97}$ POST30/4783 General Papers Relating to the Post Office Medical system. Part Two: The Medical Attendance, Medical Officers, Capitation Allowances, February 1868.

${ }^{98}$ POST 64.1, 162.

${ }^{99}$ The Lancet, 98, Issue 2519, 9 December 1871, 827-828.

${ }^{100}$ POST 64/1, 162, 189.

101 POST 64.1, 213; 1871 [Cd 438] Seventeenth report of the Postmaster General on the Post Office, 25; 1872

[Cd 645] Eighteenth report of the Postmaster General on the Post Office, 18-19.

102 POST 64.1, 212.

${ }^{103}$ His death warranted a short notice in the British Medical Journal, 30; 2(1135), 30 September 1882, 639.
} 


\section{Conclusion}

From 1855 onwards, the Post Office established a large and comprehensive medical department that by the end of the century covered the entire United Kingdom and oversaw the lives of a diverse and rapidly expanding workforce. Medical officers were employed at all stages of an employee's working life: from the initial physical examination, through to the final decision whether or not to grant a pension or gratuity. During the intervening period they provided advice and medication, they visited sick workers in their own homes and they signed off sickness payments. Their service was increasingly provided free of charge to Post Office employees, and by the end of the nineteenth century it would not be an exaggeration to say that the Post Office provided the largest and most extensive range of medical services of any branch of the Civil Service - or, indeed of any employer in the country.

For doctors, the Post Office also presented a range of opportunities, and in the shape of the first permanent medical officer, Dr Waller Lewis, it was able to attract a particularly well qualified and energetic individual with excellent connections. But even for provincial medical officers, the Post Office was a relatively lucrative position and it attracted many able medical men and, towards the end of the century, a handful of women. In the 1890s there were questions about whether separate sanitary inspectors should also oversee Post Offices instead of the local medical officers. This threat to one of the traditional Post Office doctor's role prompted the creation of the British Postal Medical Officers Association in 1894, which opposed any further efforts to erode their authority or scope of action in the Post Office. ${ }^{104}$ Post Office doctors proved to be an influential group and at the 1896 annual meeting Sir Walter Foster, MP enthusiastically replied to a toast suggesting that more Post Office medical men should be entered into the House of Lords. ${ }^{105}$ At the 1910 meeting the

\footnotetext{
${ }^{104}$ The Lancet, 144, Issue 3704, 25 August 1894, 460.

${ }^{105}$ The Huddersfield Daily Chronicle May 20, 1896.
} 
Postmaster General, Herbert Samuel, felt compelled to make a speech on the important role of the medical officers, including mention of their work on telegraphist's cramp which had been accepted as an industrial injury under the Workmen's Compensation Act and their efforts to prevent its occurrence. ${ }^{106}$ By the 1930 s the medical department had extended its remit even further and had begun to see itself not just as a service to maintain a healthy workforce but also as an important site for medical research in its own right. Writing in 1936, Sir Henry Bashford, the sixth Chief Medical Officer, listed the opportunities for research, such as the 4,000 or so records of pulmonary tuberculosis that dated back twenty years, and his successes, including proving that childhood cases of albuminuria did not determine any medical problems later on in life. ${ }^{107}$

It is important to acknowledge the vital role the Post Office played in the early history of occupational health in Britain. As one of the largest public employers in the country with a national coverage and a highly diverse set of employees, the Post Office recognised from a very early stage the importance of medical provision. Even before the widespread provision of pensions, it acted promptly, appointing highly qualified practitioners to oversee its operations, and expanding the service in both size and scope to match the growing workforce. Though traditionally side-lined or even ignored in official histories of the Post Office, medical officers had much more influence and agency within the lives of the postal staff than has been previously recognised. ${ }^{108}$ And in the context of a rapidly growing service sector, the Post Office medical service deserves far more attention in the history of occupational health than it has hitherto received.

\footnotetext{
${ }^{106}$ British Medical Journal, 30 July 1910.

107 Bashford, Post Office Medical Service, 7-9.

108 See, for example, Duncan Campbell-Smith, Masters of the Post (London: Allen Lane, 2011); Martin Daunton, Royal Mail: the Post Office since 1840 (London: Athlone, 1985).
} 
1. 1. $\quad 105+109$

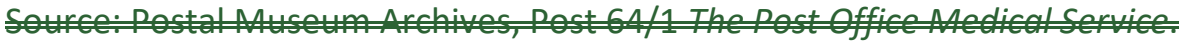

